\title{
CORRELATION BETWEEN QUALITY RATING SYSTEMS AND PROFITABILITY OF SERBIAN HOTELS
}

\author{
Slavko Alčaković, \\ Vule Mizdraković, \\ Vladimir Džamić
}

Singidunum University, Belgrade, Serbia

Correspondence:

Slavko Alčaković

e-mail:

salcakovic@singidunum.ac.rs

\begin{abstract}
:
The purpose of this paper is to investigate the connection between the quality rating systems and profitability of Serbian hotels. Having in mind that the hotel industry is market-oriented with a high proportion of fixed costs in total costs, it is a great challenge for hotel management to maintain the profitability at a satisfying level in order to keep the business running. It can be presumed that the hotels that provide high-quality services will have better ratings, higher demand, and therefore, better profitability in comparison to other hotels. In order to analyze the relationship between the quality ratings and profitability of Serbian hotels, the authors conducted research that included 51 hotels in the Republic of Serbia. The authors used multivariate analysis of variance (MANOVA) and Pearson's correlation coefficient for the analysis of the results. The results reveal a positive correlation between the selected financial ratios (return on equity and earnings before interest and taxes to average total revenue) with the hotels' official star ratings. Likewise, MANOVA showed a connection between the selected quality system ratings and financial ratios: retained earnings to total assets, profit margin and ROE.
\end{abstract}

Keywords:

fixed costs, management, services.

\section{INTRODUCTION}

The tourism industry is one of the biggest industries in the world economy. According to the World Trade Organization (WTO), there were 1,184 million international tourists (overnight guests) in 2015, which is an increase by $4.4 \%$ in comparison to the year 2014 and $8.2 \%$ in comparison to the year 2013 (World Tourism Organisation, 2016). These industries showed a steady increase of $4 \%$ yearly ever since 2010 and the alleged end of the economic crisis until 2015. Regarding the separate regions of the world, the same organization claims that European countries recorded an even higher growth rate in 2015, around 5\%, while Central and Eastern Europe recorded an increase of $6 \%$. As noted, there are positive external effects on further development of the hotel industry in this region and therefore, in the Republic of Serbia. The Republic of Serbia is a country where people love to travel - some for city breaks or weekend breaks, some for the summer holiday. In 2015, Lonely Planet, the world's largest travel guidebook publisher, named Serbia one of the Top 10 most attractive countries to visit in 2015, putting the country in the seventh place, after Singapore, Namibia, Lithuania, Nicaragua, Ireland, Congo and 
before the Philippines, St. Lucia and Morocco (InSerbia, 2015). After 1999 and the end of political instabilities in the region, the number of travellers increased over the last decade. Borovčanin (2015) shows in his research (Figure 1) that the number of travelers has been constantly increasing, with a staggering increase in 2013.

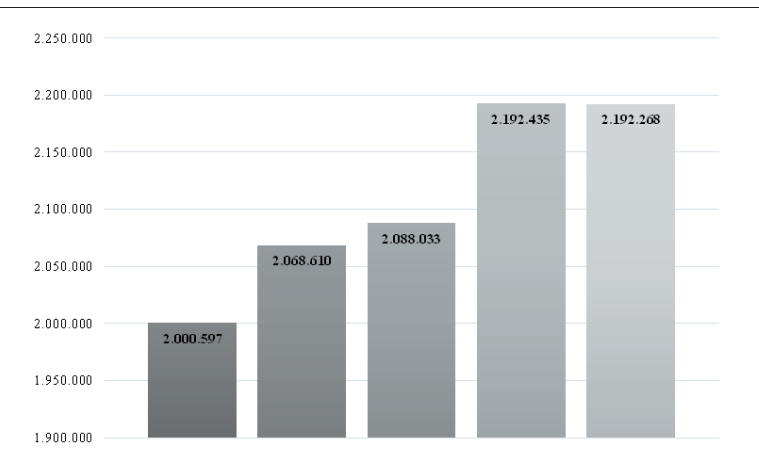

Figure 1. Number of tourist overnight stays in the Republic of Serbia for the observed period

Source: Borovčanin (2015)

However, increased interest in Serbian hotels does not have to be directly associated with the increased occupancy and profitability. Hotel management has to keep the quality of facilities and service quality in check. At the same time, they have to keep profitability at a high level in order to survive the market competition. The increasing total number of foreign overnight stays and the number of visitors creates the necessity for travelers to have some kind of guide when choosing the accommodation (Borovčanin, 2015). Most of them rely on the hotel's rating. The hotel rating system is mostly used as an indicator of the hotels' quality of service and their facilities. At the same time, rating systems can be used as a promotional tool, since hotel operators value the classification awards and grading as promotional assets (Callan, 1989 ). Also, the same author claims that classification schemes provide a significant amount of business and demand for the hotels. Other researchers (Vallen and Vallen, 2005) showed that there is an approximately $20 \%$ increase in sales among the top-rated hotels in the Mobile Guide and a 40\% increase in business among small hotels rated in AAA, after hotels were awarded with classifications. Hotels also perceive ratings as a pricing tool. Israeli and Uriely (2000) found that the price variations could be partially explained by star ratings, and the star rating system was a significant predictor of hotels' decisions in setting prices. When choosing hotels, customers who stay at three- to five-star (or other equivalent symbols) hotels use rating systems more of- ten than those staying at one- and two-star hotels (Callan, 1995). Based on the above-mentioned, the authors are interested in investigating whether there is a correlation between the quality rating systems and profitability of Serbian hotels. The research was conducted in 51 hotels and included the analysis of profitability based on the financial statements and their rating systems (official star rating by government and booking.com rating). The paper is structured as follows: in the first part, we will explain the rating systems in Serbia and their importance. The characteristics of profitability in the hotel industry and the main financial ratios will be discussed in the second part. The final part elaborates on the research results, followed by conclusions and suggestions.

\section{QUALITY RATING SYSTEMS}

As previously explained, the increasing total number of foreign overnight stays and the actual number of visitors creates the necessity for travellers to have some kind of guide when choosing the accommodation. Most of them rely on a hotel's rating. The WTO and the International Hotel and Restaurant Association define the hotel rating as the classification of accommodation establishments denoting a system, duly published, 'in which accommodation establishments of the same type (e.g., hotels, motels, and inns) have been conventionally broken down into classes, categories, or grades, according to their common physical and service characteristics and established at government, industry or other private levels (WTO, 2014).

The European Standardization Committee (CEN, Comité Européen de Normalisation) clarifies the term 'accommodation rating or classification scheme' as 'a system providing an assessment of the quality standards and provision of facility and/or service of tourist accommodation, typically within five categories, often indicated by one to five symbols' (WTO, 2004, p. 68).

The hotel rating systems can be divided into two groups: official and unofficial (Qing and Liu, 1993). Official hotel rating systems are conducted by the government body, while unofficial hotel rating systems are developed and implemented by private organizations, such as hotel or tourism associations and national or regional associations, on a voluntary participation basis by hotels. The quality level of the hotel is communicated with a variety of grading symbols, such as stars, crowns, diamonds, suns, or letters. The most universally recognized symbol is the star, as most countries have at least one rating system using stars to represent quality grades (Callan, 1993; WTO, 2004). 
In the Republic of Serbia, the official hotel rating is conducted by the Ministry of Trade, Tourism and Telecommunications. This government body issued the rulebook in 2010 with the exact classification of the star level requirement. The criteria for categorization are classified into two groups (MTT, 2012):

- Mandatory elements that are not scored,

- Elective or optional elements used for score board.

Optional elements include the basic and additional services and supporting hotel facilities. Within the mandatory and optional elements of the Rulebook, there are 182 categories and 239 individual elements. For each category of hotel star rating, the facilities need to have a certain number of points from the optional elements. More precisely, it is necessary that the hotel has a certain number of points, in addition to all the mandatory elements: 30 points for 1 star, 50 points for 2 stars, 70 points for 3 stars, 90 points for 4 stars and 110 points for 5 stars.

The authors want to emphasize that the classification of tourism accommodation worldwide is a very difficult process. Frédéric Pierret stresses two main reasons for this situation: first, because of diversity of the type of tourism accommodation, and secondly, because of the large diversity of classification systems that are themselves embedded in highly different cultural and economic contexts (Pierret, 2013). For that and many other reasons, no standardized international classification system has been adopted (Čačić, 2010). Every country has its own way of officially rating hotels, which in the end, impacts the results of hotel categorization, where 5 stars in London is not the same as 5 stars in Thessaloniki and so on. Also, you can find outliers with the zero hotel star rating in Switzerland (Null Stem Hotel) and seven star rating in the United Arab Emirates (Burj Al Arab Hotel).

Because of this information, travellers also rely on customer reviews. Booking.com is deemed one of the best hotel booking sites that travellers use for booking their accommodation and has useful customer reviews (Top ten reviews, 2016). These reviews are considered very useful because the customers need to have proof that they stayed at the facilities, whereas for others (Trip Advisor) they do not need to have proof, so anyone can rate the hotel. At Booking.com travellers can rate: cleanliness, comfort, location, facilities, staff, value for money and free Wi-Fi. They can use the following grades: $1-3$ (Very poor), 3-5 (Poor), 5-7 (Okay), 7-9 (Good), 9+ (Wonderful). It is expected that the hotel with high official and unofficial ratings should attract more customers and therefore, make more profit. However, that may not always be the case because the hotel industry has some specific characteristics.

\section{PROFITABILITY OF SERBIAN HOTELS}

Like all other business entities, hotels exist in order to make a profit by continuously creating value for the customers. In order to maintain continuous business operations, entities have to earn or create more value with the invested capital. Namely, by performing the main revenue-generating activity, an entity is using available assets and the costs are incurred. If total revenues are higher than total costs within a certain period of time, the entity is deemed profitable. All marketoriented businesses are, like the hospitality industry, relatively revenue dependent. Namely, they are usually required to maintain high revenues in order to break even generate adequate profit returns and continue its business (Graham and Harris, 1999). The problem lies in different business characteristics, because hotels usually have very high values of fixed assets. Those assets include properties - land and buildings, equipment, vehicles and even intangible assets, which are inevitable for performing hospitality services. Land and buildings usually have the highest proportion in total value of fixed assets.

Hotels have at least two options for obtaining these valuable assets; they can buy them or lease them. Except for land (in some situations, even land is depreciated) all other fixed assets incur depreciation and amortization costs. Even if the hotel lease asset and retain the incidents of ownership, it should still depreciate those assets. Also, if a hotel operates under franchise, the franchise fee will usually be recorded as an intangible asset on the balance sheet and amortized over a certain period of time. With regard to amortization calculation for tax purposes in Serbia, franchise fees are amortized over a period of ten years using the straight line method. Franchise fees are included in the second group of assets being amortized/ depreciated (Ministry of Finance RS, 2010). Therefore, hotels should expect high depreciation and amortization costs in their income statements, which will decrease their gross profit and EBIT (earnings before interest and taxes). This is the reason why hotels are considered market-oriented, since they have a high proportion of fixed costs to total costs (Kotas, 1975).

The problem of retaining the profitability at a required level by hotel management can be magnified by the seasonal character of the hotel industry. In particular, due to unstable demand, hotels have to plan and calculate the total revenues and costs for the whole season in order to have balanced profitability. Industries characterized by high fixed costs, and hotels in particular, should use the break-even concept as a useful managerial tool. 
For example, they can calculate break-even occupancy. In order to calculate this value, the total hotel contribution margin should be divided by the number of rooms occupied for the period. Then, the total hotel fixed costs should be divided by the contribution margin per room occupied (Graham and Harris, 1999). Also, the total fixed costs could be increased with a planned amount of profit that the entity wants to generate, and thus, we can calculate the required room occupancy in order to achieve the planned amount of profit.

The profitability level of a certain entity can be measured by different financial ratios. The most commonly used are listed in the table below and will be used in our research, which will be explained in the third part of the paper. However, there are a few financial ratios specific to the hotel industry, and one of those is fixed assets turnover. This ratio is calculated when fixed assets are divided with sales revenue, and it indicates how much revenue the hotel earns with fixed assets in use.

Efficiency and high quality of service certainly affect the customer experience and ultimately a hotel's profitability level. However, quality rating systems also affect the customer experience. For example, the research, which included 6,768 hotels from 47 European capital cities, confirmed the findings of previous studies that the hotel star rating is the single most important factor that influences the customer experience (Radojevic et al., 2015). One should bear in mind that the reported level of satisfaction of a hotel customer depends on the demographic categories, as well. According to Radojevic et al. (2015), solo travellers assign higher ratings than families. The authors argue that considerable differences exist within the baseline level of satisfaction, and that the importance of certain factors varies across the categories: solo travelers, groups of friends, couples and families (Radojevic et al., 2015a). In the final part of the paper, the authors shall address the effect of quality rating systems on profitability.

\section{THE EFFECT OF QUALITY RATING SYSTEMS ON PROFITABILITY OF SERBIAN HOTELS}

In this part, we will present the results of the research that analyses the correlation of quality rating systems with the profitability of Serbian hotels. In order to analyze the profitability of sampled hotels, we needed their complete set of financial statements. There were only 54 hotels that fulfilled that requirement and they were included in this research. They are mostly large and medium-size business entities according to the official classification of business entities in the Republic of Serbia. We gathered their financial statements for the observed period from the official site of the Serbian Business Registers Agency. The financial ratios related to the profitability of sampled hotels were calculated.

The next step was collecting the data regarding the rating systems of the sampled hotels. We have the official governmental star rating system for each hotel for the observed period. Out of 54 hotels, 51 had information on the official star rating and therefore, only they were included in further research. The results show that most hotels have three and four stars (35\% for each group). We used the Booking.com rating system as a comparable unofficial rating system. The results show that $27.8 \%$ of sampled hotels have ratings on Booking. com between 8 and 9. However, 31.5\% of sampled hotels do not have Booking.com ratings. We included in the Appendix the table that presents the classification of sampled hotels per those two rating systems. During

Table 1. Financial ratios used in the research

\begin{tabular}{lccccc}
\hline \multicolumn{1}{c}{ Financial ratios } & No & Minimum & Maximum & Mean & Std. Deviation \\
\hline Retained earnings to average total assets & 51 & 0.00 & 0.89 & 0.08 & 0.17 \\
\hline EBIT to average total assets & 51 & -0.15 & 0.94 & 0.02 & 0.14 \\
\hline Revenues to average total assets & 51 & 0.02 & 3.45 & 0.38 & 0.55 \\
\hline Profit margin & 51 & -0.93 & 0.30 & -0.09 & 0.28 \\
\hline ROE & 51 & -0.69 & 1.42 & -0.02 & 0.27 \\
\hline Fixed asset turnover & 51 & 0.00 & 0.95 & 0.30 & 0.24 \\
\hline EBIT depreciation to average total liabilities & 51 & -0.21 & 1.91 & 0.01 & 0.57 \\
\hline EBIT to total revenue & 51 & -3.40 & 0.38 & -0.12 & 0.56 \\
\hline Revenue to average total assets & 51 & 0.02 & 1.93 & 0.32 & 0.33 \\
\hline
\end{tabular}

Source: Authors' data 
Table 2. The influence factors on multivariate composite (profitability) - Multivariate tests

\begin{tabular}{lccccc}
\hline Quality rating system & Wilks & F & Hypothesis df & Error df & Sig. \\
\hline Booking.com & 0.053 & 2.59 & 32 & 67.976 & 0.001 \\
\hline Official star rating & 0.123 & 2.333 & 24 & 52.807 & 0.005 \\
\hline
\end{tabular}

Source: Authors' data

this research, we gathered the information regarding the existence of an official internet web site for each sampled hotel. The authors found out that $90.2 \%$ of sampled hotels have the official Internet web site used for promotional activities.

In order to analyze the data we used descriptive statistics, which found the correlation between hotels' official star ratings and ROE with significance at 0.031 . Out of other selected financial ratios, EBIT to total revenue showed a significant correlation with hotels' official star ratings. Also, the authors employed MANOVA, and the results are presented in the following table. In MANOVA analysis, independent variables were ratings on Booking.com and official star ratings, and dependent variables were retained earnings to average total assets, EBIT to average total assets, revenues to average total assets, profit margin, ROE, fixed asset turnover, EBIT depreciation to average total liabilities, EBIT to total revenue, and revenue to average total assets.

Table 2 shows that there is a significant statistical influence of ratings on Booking.com $(\lambda=0.053 ; \mathrm{F}=2.59$; $\mathrm{df}=32 ; \mathrm{p}=0.001)$ and official star ratings $(\lambda=0.123$; $\mathrm{F}=2.333 ; \mathrm{df}=24 ; \mathrm{p}=0.005$ on selected financial ratios that measure profitability.

In Table 4 (Appendix), which presents the analysis of the influence on single variables, it can be seen that ratings on Booking.com have the biggest statistical influence on profit margin $\left(\varepsilon^{2}=0.567 ; \mathrm{F}=8.194 ; \mathrm{df}=4 ; \mathrm{p}<0.001\right)$, and immediately afterwards, on retained earnings to total assets $\left(\varepsilon^{2}=0.388 ; \mathrm{F}=3.39 ; \mathrm{df}=4 ; \mathrm{p}=0.013\right)$ and then on EBIT to total revenue $\left(\varepsilon^{2}=0.353 ; \mathrm{F}=3.405 ; \mathrm{df}=4 ; \mathrm{p}=0.024\right)$ and the lowest on $\operatorname{ROE}\left(\varepsilon^{2}=0.33 ; \mathrm{F}=3.079 ; \mathrm{df}=4 ; \mathrm{p}=0.013\right)$. When the influence of the official star rating on individual financial ratings was analyzed, the results showed that the statistical influence exists only for $\operatorname{ROE}\left(\varepsilon^{2}=0.339\right.$; $\mathrm{F}=4.28 ; \mathrm{df}=4 ; \mathrm{p}=0.014)$ and retained earnings to total assets $\left(\varepsilon^{2}=0.324 ; \mathrm{F}=3.998 ; \mathrm{df}=3 ; \mathrm{p}=0.019\right)$.

Detailed information regarding the effects of quality rating systems on selected profitability financial ratios can be found in the Appendix.

\section{CONCLUSIONS}

Tourism is the fastest growing industry in the world. Due to economic globalization, the rise in the number of foreign tourists has led to positive changes in the Serbia's economy, including the increased demand for Serbian hotels and the number of foreign hotel customers. Research has shown that the profitability of the hotel industry largely depends on the official categorization granted by the Ministry of Trade, Tourism and Telecommunications of the Republic of Serbia, as well as unofficial categorization, such as by Booking.com. Ranking and categorization may suggest better quality of service to potential visitors, which will lead to higher demand, and ultimately, hotels will earn more profit. However, the question that remains open for further research is the official categorization of tourism accommodation at the global level and harmonization of different standards in this field.

\section{REFERENCES}

Čačić, K. (2010). Poslovanje hotelskih preduzeća. Beograd: Univerzitet Singidunum.

Borovčanin, D. (2015). Comparative analysis of eeconomic financial ratios of hotels with 4 star rating. Belgrade: Master thesis Singidunum University.

Callan, R.J. (1995). Hotel classification and grading schemes, a paradigm of utilization and user characteristics. International Journal of Hospitality Management, 14(3-4), 271-283. doi:10.1016/0278-4319(95)00030-5

Callan, R.J. (1993). An appraisal of UK hotel quality grading schemes. International Journal of Contemporary Hospitality Management, 5(5), 10-18. doi:10.1108/09596119310046907

Callan, R.J. (1989). Small country hotels and hotel award schemes as a measurement. The Service Industries Journal, 9(2), 223-246. doi:10.1080/02642068900000026 
Graham, I., \& Harris, P. (1999). Development of a Profit Planning Framework in an International Hotel Chain: A Case Study. International Journal of Contemporary Hospitality Management, 11(5), 198-208. doi:10.1108/09596119910272694

InSerbia. (2015). Lonely Planet: Serbia one of Top 10 most attractive countries to visit in 2015. Retrieved July 27, 2016, from InSerbia:

http://inserbia.info/today/2014/10/lonely-planetserbia-one-of-top-10-most-attractive-countries-tovisit-in-2015/

Israeli, A.A., \& Uriely, N. (2000). The impact of star ratings and corporate affiliation on hotel room prices in Israel. Tourism and Hospitality Research, 2(1), 27-36.

Kotas, R. (1975). Market Orientation in the Hotel and Catering Industry. Glasgow: Blackie Academic \& Professional.

Ministry of Finance RS. (2010). Rules on the Classification of Fixed Assets on Groups and Depreciation Calculation for Tax Purposes. Retrieved from Ministry of Finance: Tax administration:

http://www.purs.gov.rs/sr/pravna-lica/pregledpropisa/pravilnici/321/pravilnik-o-nacinu-razvrstavnja-stalnih-sredstava-po-grupama-i-nacinuutvrdjivanja-amortizacije-za-poreske-svrhe.html

MTT. (2012). Pravilnik o kategorizaciji sa prilozima. Retrieved July 27, 2016, from Ministarstvo trgovine, turizma i telekomunikacije: http://mtt.gov.rs/ download/PRAVILNIK\%20O\%20STANDARDIMA\%20ZA\%20KATEGORIZACIJU.pdf
Pierret, F. (2013). About Hotel Classification Systems. Retrieved september 15, 2016, from World tourism organization: http://www2.unwto.org/agora/ about-hotel-classification-systems

Radojevic, T., Stanisic, N., \& Stanic, N. (2015). Ensuring Positive Feedback: Factors that Influence Customer Satisfaction in the Contemporary Hospitality Industry. Toursim Mangement, 51(1), 13-21.

doi:10.1016/j.tourman.2015.04.002

Radojevic, T., Stanisic, N., \& Stanic, N. (2015a). Solo Travellers Assign Higher Ratings than Families: Examining Customer Satisfaction by Demographic Group. Tourism Management Perspectives, 16(1), 247-258. doi:10.1016/j.tmp.2015.08.004

Top ten reviews. (2016). Hotel Booking Services Reviews - Top Best 2016. Retrieved July 27, 2016, from Hotel booking services review toptenreviews: http:// hotel-booking-services-review.toptenreviews.com/

Vallen, G.K., \& Vallen, J.J. (2005). Check-in, check-out: Managing hotel operations. Upper Saddle River, NJ: Pearson Prentice Hall.

World Tourism Organisation. (2016). International tourist arrivals up 4\% reach a record 1.2 billion in 2015. Retrieved July 27, 2016, from World Tourism Organisation UNWTO:

http://media.unwto.org/press-release/2016-01-18/ international-tourist-arrivals-4-reach-record12-billion-2015

WTO. (2014). The Joint WTO \& IH\&RA Study on Hotel Classification. Madrid: WTO.

doi:10.18111/9789284407194

\section{APPENDIX}

Table 3. Classification of sampled hotels per rating systems

\begin{tabular}{lcclcc}
\hline & Booking.com rating & & \multicolumn{3}{c}{ Official hotel star rating } \\
\hline \multicolumn{1}{c}{ Rating } & $\begin{array}{c}\text { Number of } \\
\text { hotels }\end{array}$ & Percent & Number of stars & $\begin{array}{c}\text { Number of } \\
\text { hotels }\end{array}$ & Percent \\
\hline No rating & 17 & 33.3 & One star & 1 & 2 \\
\hline Between 5-7 & 3 & 5.9 & Two stars & 8 & 15.7 \\
\hline Between 7-8 & 8 & 15.7 & Three stars & 19 & 37.3 \\
\hline Between 8-9 & 15 & 29.4 & Four stars & 19 & 37.3 \\
\hline Between 9-10 & 8 & 15.7 & Five stars & 4 & 7.8 \\
\hline Total & 51 & 100 & Total & 51 & 100 \\
\hline
\end{tabular}

Source: Authors' data 
Table 4. The influence of individual variables if they are isolated - Test of Between - Subjects Effects

\begin{tabular}{|c|c|c|c|c|c|c|c|}
\hline Source & Dependent variable & $\begin{array}{l}\text { Type III Sum } \\
\text { of Squares }\end{array}$ & $\mathrm{df}$ & $\begin{array}{l}\text { Mean } \\
\text { Square }\end{array}$ & $\mathrm{F}$ & Sig. & $\begin{array}{c}\text { Partial Eta } \\
\text { Squared }\end{array}$ \\
\hline \multirow[t]{9}{*}{ Booking.com } & $\begin{array}{l}\text { Retained earnings tototal } \\
\text { assets }\end{array}$ & 0.15 & 4 & 0.037 & 3.97 & 0.013 & 0.388 \\
\hline & EBIT to total assets & 0.004 & 4 & 0.001 & 0.687 & 0.607 & 0.099 \\
\hline & Revenues to total assets & 0.082 & 4 & 0.021 & 0.426 & 0.789 & 0.064 \\
\hline & Profit margin & 1.139 & 4 & 0.285 & 8.194 & 0 & 0.567 \\
\hline & ROE & 807.96 & 4 & 201.99 & 3.079 & 0.034 & 0.33 \\
\hline & Fixed asset turnover & 0.083 & 4 & 0.021 & 0.351 & 0.841 & 0.053 \\
\hline & EBITDA to total liabilities & 9.743 & 4 & 2.436 & 0.061 & 0.993 & 0.01 \\
\hline & EBIT to total revenue & 0.373 & 4 & 0.093 & 3.405 & 0.024 & 0.353 \\
\hline & Revenue to total assets & 0.082 & 4 & 0.021 & 0.426 & 0.789 & 0.064 \\
\hline \multirow[t]{9}{*}{$\begin{array}{l}\text { Hotels' official } \\
\text { star ratings }\end{array}$} & $\begin{array}{l}\text { Retained earnings tototal } \\
\text { assets }\end{array}$ & 0.113 & 3 & 0.038 & 3.998 & 0.019 & 0.324 \\
\hline & EBIT to total assets & 0.008 & 3 & 0.003 & 1.723 & 0.188 & 0.171 \\
\hline & Revenues to total assets & 0.052 & 3 & 0.017 & 0.361 & 0.782 & 0.041 \\
\hline & Profit margin & 0.216 & 3 & 0.072 & 2.068 & 0.13 & 0.199 \\
\hline & ROE & 842.339 & 3 & 280.78 & 4.28 & 0.014 & 0.339 \\
\hline & Fixed asset turnover & 0.03 & 3 & 0.01 & 0.167 & 0.918 & 0.02 \\
\hline & EBITDA to total liabilities & 21.902 & 3 & 7.301 & 0.183 & 0.907 & 0.022 \\
\hline & EBIT to total revenue & 0.184 & 3 & 0.061 & 2.241 & 0.108 & 0.212 \\
\hline & Revenue to total assets & 0.052 & 3 & 0.017 & 0.361 & 0.782 & 0.041 \\
\hline
\end{tabular}

Source: Authors' data 